О.В. Вовк, В.О. Іщук, О.М. Компанієць, Д.В. Литвинчук, М.В. Туленко

Харківський національний університет Повітряних Сил ім. І. Кожедуба, Харків

\title{
РЕЗУЛЬТАТИ ПОРІВНЯЛЬНОГО ОЦІНЮВАННЯ СИСТЕМИ ЛЬОТНОЇ ПІДГОТОВКИ КУРСАНТІВ ЛЬОТЧИКІВ ТАКТИЧНОЇ АВІАЦІЇ ПОВІТРЯНИХ СИЛ ЗБРОЙНИХ СИЛ УКРАЇНИ КОМПЛЕКСНИМ КРИТЕРІЄМ ОЦІНКИ ЕФЕКТИВНОСТІ
}

Розроблено кваліметричну модель оцінки системи льотної підготовки курсантів льотчиків тактичної авіації Повітряних Сил Збройних Сил Украӥни, яка у векторній формі дозволяє здійснити оиінку ефективності впроваджених відповідних систем підготовки. Проведено розрахунок значень комплексного критерію оцінки ефективності системи льотної підготовки, впровадженої в Харківському національному університеті Повітряних Сил. Отримані результати дозволяють враховувати особливості льотної підготовки та їх вплив на систему бойової підготовки Повітряних Сил Збройних Сил України.

Ключові слова: трьохступенева система підготовки, рівень підготовки льотного складу, ефективність.

\section{Вступ}

Постановка проблеми. На сьогоднішній день існує багато підходів до оцінювання ефективності різних систем, які дозволяють побудувати математичні моделі для розрахунку показників їх ефективності [1]. Етапами системи льотної підготовки $є$ послідовні ступені, що забезпечують досягнення певної мети або кінцевих цілей притаманних галузі досліджень. Відповідно до основних принципів системного аналізу їх потенційна ефективність повинна оцінюватися через вплив на ефективність системи льотної підготовки в цілому. Такого роду вплив може бути оціненим через оцінку властивостей відповідної системи льотної підготовки за рахунок застосування кваліметричних моделей [2-3].

Критерієм оцінювання ефективності виконання процесу підготовки можна обрати комплексний критерій, який представляє собою відношення ефекту від виконання етапів системи льотної підготовки до часових витрат або вартісних витрат [4]. Максимальне значення комплексного критерію свідчитиме про якість виконання системи льотної підготовки в цілому.

Аналіз останніх досліджень і публікацій. Науково обгрунтованою оцінкою ефективності виконання будь-яких проектів у тому числі систем підготовки, можуть бути результати порівняння етапів виконання підготовки та відповідна оцінка якості проведених заходів [4]. Для розгляду відповідного питання доцільно провести оцінку ефективності кожного етапу (ступеня) льотної підготовки окремо та відповідно в цілому системи льотної підготовки. Аналіз даного питання дозволяє зробити висновок, що у певних випадках вихідні дані для розрахунку критерію ефективності системи льотної підготовки можуть бути неповні, або зовсім відсутні, якщо про- ект має інноваційний характер.

Відповідно, для урахування впливу фактичного рівня підготовки льотного складу на ефективність виконання завдань за призначенням, необхідно створити кваліметричну модель, яка б найбільш повним чином враховувала і віддзеркалювала рівень підготовки льотчика в сучасних умовах.

Мета статті полягає у науково-обгрунтованій порівняльній оцінці ефективності запровадженої в Харківському національному університеті Повітряних Сил трьохступеневої системи льотної підготовки курсантів льотчиків тактичної авіації з відомими альтернативами, що застосовувалися раніше, або ті, які можуть бути запроваджені у майбутньому. Критерієм оцінювання ефективності льотної підготовки курсантів льотчиків для тактичної авіації Повітряних (ПС) Сил Збройних Сил (3С) України доцільно застосовувати комплексний критерій, який повинен представляти собою відношення ефекту льотної підготовки до витрат на відповідну підготовку.

\section{Виклад основного матеріалу}

В якості інструментарію для рішення такої задачі можуть бути застосовані евристичні методи, а саме методи на основі експертних оцінок [8-12]. Аналіз даного питання дозволяє зробити висновок, що визначена задача $є$ слабо структурованою та нечітко формалізована, а тому з великої кількості експертних методів доцільно застосування методу, в основу якого полягають експертно-аналітичні процедури, що описані в методі аналізу ісрархій (MAI) [5-11]. МАI дозволяє групі фахівців взаємодіяти по відповідній тематиці, модифікувати свої судження і в результаті об'єднувати групові судження у відповідності до визначальних критеріїв, а саме при проведенні попарних порівнянь об'єктів по відношенню 
до деякої властивості, або властивостей по відношенню до головної мети. Зворотні зв'язки забезпечують шлях до об'єднання групових суджень в раціональне рішення.

Методичний підхід до вирішення відповідної задачі з оцінки ефективності системи льотної підготовки описано в роботі [4]. Виконання системи льотної підготовки умовно або нормативно може бути представлено як сукупність етапів системи льотної підготовки, які у адитивній формі мають вигляд як $\sum$ Emanis $_{z}=1$.

В якості критерію оцінювання ефективності системи льотної підготовки (етапів системи льотної підготовки) обирається максимум комплексного показника, що описує повне співвідношення ефекту, отриманого від виконання сукупності ступеней системи льотної підготовки до узагальнених витрат. Головною метою досягнення відповідного рівня підготовки обрано присвоєння льотному складу кваліфікації “льотчика 3 класу”.

Комплексний критерій оцінки ефективності застосування системи льотної підготовки визначено нижче:

$$
\Omega_{\text {eфj }}=\frac{\text { Ефект }_{j}}{\text { Buтрати }_{j}} \rightarrow \max .
$$

де $\Omega_{e \phi j}-$ комплексний критерій оцінки ефективності відповідного $j$-ого етапу системи льотної підготовки;

Eфекm $_{j}$ - векторне значення ефекту застосування $j$-ого етапу системи льотної підготовки;

Buтрати $_{j}$ - векторне значення витрат відповідного $j$-ого етапу системи льотної підготовки.

На основі аналізу льотної підготовки курсантів льотного факультету евристичними методами умовно визначені наступні групи навичок та умінь, які повинні опанувати курсанти під час їх підготовки і які можна обирати у вигляді сукупності властивостей для визначення ефекту льотної підготовки:

- навігація $\left(K_{1}\right)$ - навички, якими можна охарактеризувати властивість визначення місцеположення літального апарату (ЛА), параметрів руху, літаководіння, тощо;

- техніка пілотування $\left(K_{2}\right)$ - уміння, які отримує курсант для керування рухом ЛА, утримування кутового положення і параметрів траєкторії польоту ЛА при вирішенні цільової задачі;

- застосування за призначенням $\left(K_{3}\right)$ навички, отримані для використання ЛА за основним призначенням (бойове застосування);

- льотно-тактичні навички $\left(K_{4}\right)$ - навички дій екіпажів ЛА по веденню бойових дій (виконанню бойових задач) поодиноко та в складі підрозділів.
Мета "Goal” (оцінка ефекту льотної підготовки) буде полягати у визначенні пріоритетів виконання ступеней льотної підготовки для досягнення відповідного класу:

- первинна льотна підготовка $\left(P_{1}\right)$;

- основна льотна підготовка $\left(P_{2}\right)$;

- підвищена льотна підготовка $\left(P_{3}\right)$.

Метою "Goal” (Ефект) є ранжування етапів системи льотної підготовки та визначення оптимального етапу з числа альтернатив $\left\{P_{1}, \ldots P_{z}\right\}$, де $z-$ кількість етапів системи льотної підготовки.

Отримання інтегральної оцінки ефективності системи льотної підготовки здійснюється шляхом оцінювання внеску кожної з визначених властивостей $\left\{K_{1}, \ldots K_{n}\right\}$ в узагальнену оцінку ефективності його функціонування. Ієрархія представлена на рис. 1.

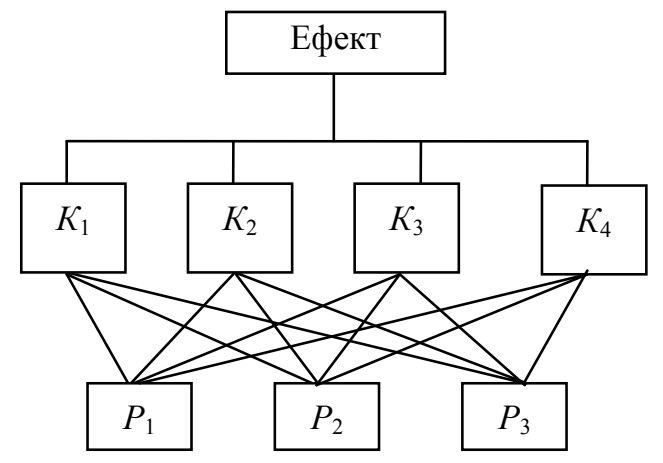

Рис. 1. Ієрархія визначення ефективності виконання системи льотної підготовки

Результати порівняння етапів системи підготовки представлені за МАI зведені до табл. 1-6, які представляють собою матриці попарних порівнянь (МПП) 3 розрахованими локальними векторами пріоритетів, максимальними власними значеннями, індексами погодженості та відношеннями погодженості.

Таблиця 1

МПП критеріїв одного рівня ієрархії між собою

\begin{tabular}{|c|c|c|c|c|c|}
\hline Критерії & $K_{1}$ & $K_{2}$ & $K_{3}$ & $K_{4}$ & $\begin{array}{c}\text { Оцінка } \\
W\end{array}$ \\
\hline$K_{1}$ & 1 & $1 / 7$ & $1 / 5$ & 3 & 0,1 \\
\hline$K_{2}$ & 7 & 1 & $1 / 2$ & 7 & 0,41 \\
\hline$K_{3}$ & 5 & 2 & 1 & 3 & 0,43 \\
\hline$K_{4}$ & $1 / 3$ & $1 / 7$ & $1 / 3$ & 1 & 0,06 \\
\hline
\end{tabular}

Аналіз отриманих значень локального вектору пріоритетів $W=(0,1 ; 0,41 ; 0,43 ; 0,06)$ з отриманими критеріями погодженості МПП $\lambda_{\max }=4,44$, $C I=0,147, C R=16,33 \%$ дозволяє зробити висновок, що групове судження визначено 3 достатнім ступенем достовірності і відповідно максимальне значення пріоритету відведене навичкам застосування ЛА за призначенням, як властивості 3 максимальним 
впливом на ефект від льотної підготовки.

Таблиця 2

МПП альтернатив відносно критерію $K_{1}$

\begin{tabular}{|c|c|c|c|c|}
\hline $\begin{array}{c}\text { Критерій } \\
K_{1}\end{array}$ & $P_{1}$ & $P_{2}$ & $P_{3}$ & $\begin{array}{c}\text { Оцінка } \\
W\end{array}$ \\
\hline$P_{1}$ & 1 & $1 / 3$ & $1 / 4$ & 0,121 \\
\hline$P_{2}$ & 3 & 1 & 3 & 0,575 \\
\hline$P_{3}$ & 4 & $1 / 3$ & 1 & 0,304 \\
\hline
\end{tabular}

Порівняння альтернатив відносно навичок та умінь 3 навігації ЛА $\left(K_{1}\right)$ можна зробити висновок щодо отриманих значень локального вектору пріоритетів $W=(0,121 ; 0,575 ; 0,304)$ критерії погодженості складають $\lambda_{\max }=3,217, C I=0,109, C R=18,74 \%$, а тому, групове судження визначено $з$ достатнім ступенем достовірності.

Максимальне значення пріоритету отримала альтернатива - основна система підготовки $\left(P_{2}\right)$.

Таблиця 3

МПП альтернатив відносно критерію $K_{2}$

\begin{tabular}{|c|c|c|c|c|}
\hline $\begin{array}{c}\text { Крите- } \\
\text { рій } \\
K_{2}\end{array}$ & $P_{1}$ & $P_{2}$ & $P_{3}$ & Оцінка $W$ \\
\hline$P_{1}$ & 1 & $1 / 7$ & $1 / 5$ & 0,078 \\
\hline$P_{2}$ & 7 & 1 & 1 & 0,487 \\
\hline$P_{3}$ & 5 & 1 & 1 & 0,435 \\
\hline
\end{tabular}

При порівнянні альтернатив відносно умінь 3 техніки пілотування $\left(K_{2}\right)$, значення локального вектору пріоритетів склали $W=(0,078 ; 0,487 ; 0,435)$ критерії погодженості складають $\lambda_{\max }=3,0126$, $C I=0,0063, C R=1,09 \%$, що в межах визначеного за MAI. Максимальне значення вектору пріоритету в основній системі підготовки $\left(P_{2}\right)$.

Таблиця 4

МПП альтернатив відносно критерію $K_{3}$

\begin{tabular}{|c|c|c|c|c|}
\hline $\begin{array}{c}\text { Критерій } \\
K_{3}\end{array}$ & $P_{1}$ & $P_{2}$ & $P_{3}$ & $\begin{array}{c}\text { Оцінка } \\
W\end{array}$ \\
\hline$P_{1}$ & 1 & $1 / 7$ & $1 / 7$ & 0,063 \\
\hline$P_{2}$ & 7 & 1 & $1 / 3$ & 0,304 \\
\hline$P_{3}$ & 7 & 3 & 1 & 0,633 \\
\hline
\end{tabular}

При порівнянні альтернатив відносно застосування за призначенням $\left(K_{3}\right)$, значення локального вектору пріоритетів склали $W=(0,063 ; 0,304 ; 0,633)$, критерії погодженості складають $\lambda_{\max }=3,136$, $C I=0,068, C R=11,69 \%$, що в межах визначеного за MAI. Максимальне значення вектору пріоритету у підвищеній системі підготовки $\left(P_{3}\right)$.

Таблиця 5

МПП альтернатив відносно критерію $K_{4}$

\begin{tabular}{|c|c|c|c|c|}
\hline $\begin{array}{c}\text { Критерій } \\
K_{4}\end{array}$ & $P_{1}$ & $P_{2}$ & $P_{3}$ & $\begin{array}{c}\text { Оцінка } \\
W\end{array}$ \\
\hline$P_{1}$ & 1 & $1 / 7$ & $1 / 7$ & 0,065 \\
\hline$P_{2}$ & 7 & 1 & $1 / 2$ & 0,361 \\
\hline$P_{3}$ & 7 & 2 & 1 & 0,574 \\
\hline
\end{tabular}

При порівнянні альтернатив відносно льотнотактичних навичок $\left(K_{4}\right)$, значення локального вектору пріоритетів склали $W=(0,065 ; 0,361 ; 0,574)$, критерії погодженості складають $\lambda_{\max }=3,054$, $C I=0,027, C R=4,62 \%$, що свідчить про потенційно велику погодженість групового судження експертів за даним питанням.

Максимальне значення вектору пріоритету у підвищеній системі підготовки $\left(P_{3}\right)$.

Таблиця 6

Визначення загальних пріоритетів

\begin{tabular}{|c|c|c|c|c|c|}
\hline \multirow{3}{*}{$\begin{array}{c}\text { Альтерна- } \\
\text { тиви }\end{array}$} & \multicolumn{5}{|c|}{ Критерії } \\
\hline & $K_{1}$ & $K_{2}$ & $K_{3}$ & $K_{4}$ & Вектор \\
\hline & 0,1 & 0,41 & 0,43 & 0,06 & $\begin{array}{c}\text { пр1ори- } \\
\text { тетів }\end{array}$ \\
\hline$P_{1}$ & 0,121 & 0,078 & 0,063 & 0,065 & 0,07 \\
\hline$P_{2}$ & 0,575 & 0,487 & 0,304 & 0,361 & 0,41 \\
\hline$P_{3}$ & 0,275 & 0,435 & 0,633 & 0,574 & 0,52 \\
\hline
\end{tabular}

Проведені дослідження свідчать про те, що групове судження щодо оцінки етапів системи льотної підготовки відрангували підвищену льотну підготовку на бойових літаках на перше місце, тобто вектор ефекту від застосування III ступені підготовки у вищому навчальному закладі складає 0,52 , що на 11\% має більший ефект від основної льотної підготовки на літаках типу L-39.

Слід зазначити про те, що лише 7\% ефекту від загального значення вектору складає підготовка на легкомоторних літаках (ЛМЛ) початкового навчання.

За аналогічною процедурою проведена оцінка економічних витрат у векторному вигляді. Для оцінки витрат для досягнення ефекту з отримання класної кваліфікації “льотчик 3 класу” необхідно провести порівняння визначених чинників та отримати векторні значення витрат.

Визначені групи економічних витрат щодо льотної підготовки:

- витрати на теоретичну підготовку $\left(X_{1}\right)$;

- витрати на тренажерну підготовку $\left(X_{2}\right)$;

- витрати на практичну підготовку $\left(X_{3}\right)$.

Оцінкою витрат на підготовку буде визначення вектору пріоритету щодо економії витрат при підготовці льотчика до рівня “3 класу” в вищому навчальному закладі:

- первинна льотна підготовка $\left(S_{1}\right)$;

- основна льотна підготовка $\left(S_{2}\right)$;

- підвищена льотна підготовка $\left(S_{3}\right)$.

Метою "Goal" (Витрати) є визначення у векторній формі витрат на відповідну систему льотної підготовки.

Отримання інтегральної оцінки економічного ефекту кожного етапу льотної підготовки шляхом оцінювання внеску кожної з визначених груп витрат $\left\{X_{1}, \ldots X_{3}\right\}$ в узагальнену оцінку витрат в цілому. Ієрархія представлена на рис. 2. 


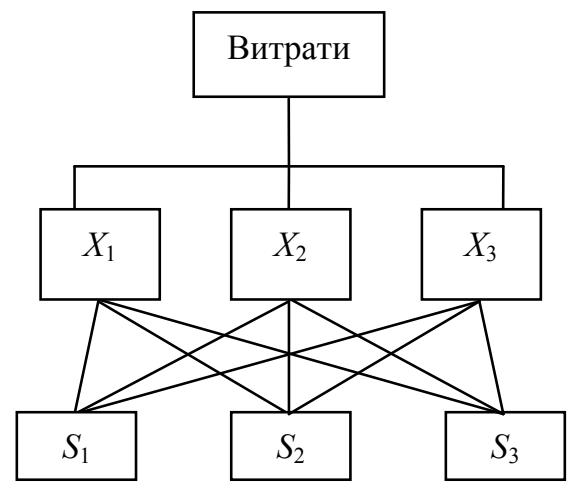

Рис. 2. Ієрархія визначення витрат на льотну підготовку

Результати порівняння об'єктів представлені в табл. 7-11. Для усіх МПП визначено оцінку локального вектору пріоритету, максимальне власне значення, індекс погодженості та відношення погодженості.

Таблиця 7

МПП критеріїв одного рівня ієрархії між собою

\begin{tabular}{|c|c|c|c|c|}
\hline Критерії & $X_{1}$ & $X_{2}$ & $X_{3}$ & Оцінка $W$ \\
\hline$X_{1}$ & 1 & $1 / 7$ & $1 / 9$ & 0,06 \\
\hline$X_{2}$ & 7 & 1 & 1 & 0,45 \\
\hline$X_{3}$ & 9 & 1 & 1 & 0,49 \\
\hline
\end{tabular}

Локальний вектор пріоритетів складає $W=(0,06$; 0,45; 0,49). Розраховані критерії погодженості МПП: $\lambda_{\max }=3,007, C I=0,04, C R=0,61 \%$ дозволяє зробити висновок, що групове судження визначено $з$ достатнім ступенем достовірності. Максимальне значення локального вектору пріоритету можна віднести до практичної підготовки $\left(X_{3}\right)$.

Таблиця 8

МПП альтернатив відносно критерію $X_{1}$

\begin{tabular}{|c|c|c|c|c|}
\hline $\begin{array}{c}\text { Критерій } \\
X_{1}\end{array}$ & $S_{1}$ & $S_{2}$ & $S_{3}$ & Оцінка $W$ \\
\hline$S_{1}$ & 1 & $1 / 6$ & $1 / 5$ & 0,078 \\
\hline$S_{2}$ & 6 & 1 & 3 & 0,635 \\
\hline$S_{3}$ & 5 & $1 / 3$ & 1 & 0,287 \\
\hline
\end{tabular}

Порівняння альтернатив відносно витрат на теоретичну підготовку $\left(X_{1}\right)$ дозволило розрахувати значення локальних векторів пріоритетів, що склали $W=(0,078 ; 0,635 ; 0,287)$. Критерії погодженості складають $\lambda_{\max }=3,09, C I=0,047, C R=8,1 \%$, а тому, групове судження визначено 3 достатнім ступенем достовірності. Максимальне значення витрат відносно теоретичної підготовки отримала альтернатива $P_{2}$ основна підготовка.

Таблиця 9

МПП альтернатив відносно критерію $X_{2}$

\begin{tabular}{|c|c|c|c|c|}
\hline $\begin{array}{c}\text { Критерій } \\
X_{2}\end{array}$ & $S_{1}$ & $S_{2}$ & $S_{3}$ & Оцінка $W$ \\
\hline$S_{1}$ & 1 & $1 / 7$ & $1 / 3$ & 0,088 \\
\hline$S_{2}$ & 7 & 1 & 3 & 0,669 \\
\hline$S_{3}$ & 3 & $1 / 3$ & 1 & 0,242 \\
\hline
\end{tabular}

При порівнянні альтернатив, щодо витрат відносно тренажерної підготовки $\left(X_{2}\right)$, значення локального вектору пріоритетів склали $W=(0,088 ; 0,669$; 0,242) критерії погодженості: $\lambda_{\max }=3,001$, $C I=0,004, C R=0,61 \%$, що в межах визначеного за MAI. Максимальне значення відповідає витратам на основну підготовку, оскільки тренажерна підготовка здійснюється під час навчання у вищому навчальному закладі і займає відповідні 2 роки.

Таблиця 10

МПП альтернатив відносно критерію $X_{3}$

\begin{tabular}{|c|c|c|c|c|}
\hline $\begin{array}{c}\text { Критерій } \\
X_{3}\end{array}$ & $S_{1}$ & $S_{2}$ & $S_{3}$ & Оцінка $W$ \\
\hline$S_{1}$ & 1 & $1 / 5$ & $1 / 9$ & 0,058 \\
\hline$S_{2}$ & 5 & 1 & $1 / 5$ & 0,207 \\
\hline$S_{3}$ & 9 & 5 & 1 & 0,735 \\
\hline
\end{tabular}

Групове експертне судження експертів визначило витратним підвищену систему підготовки на бойових літаках відносно критерію $X_{3}$. Вектор локальних пріоритетів має наступні значення $W=(0,058$; 0,207; 0,735).

Критерії погодженості складають $\lambda_{\max }=3,117$, $C I=0,059, C R=10,09 \%$, що свідчить про потенційно велику погодженість групового судження експертів за даним питанням.

Таблиця 11

Визначення загальних пріоритетів

\begin{tabular}{|c|c|c|c|c|}
\hline \multirow{3}{*}{ Альтернативи } & \multicolumn{4}{|c|}{ Критерії } \\
\hline & $X_{1}$ & $X_{2}$ & $X_{3}$ & Вектори \\
\hline & 0,06 & 0,45 & 0,49 & пріоритетів \\
\hline$S_{1}$ & 0,078 & 0,088 & 0,058 & 0,07 \\
\hline$S_{2}$ & 0,635 & 0,669 & 0,207 & 0,44 \\
\hline$S_{3}$ & 0,287 & 0,242 & 0,735 & 0,49 \\
\hline
\end{tabular}

Як видно з проведених досліджень, у векторній відносній величині витрат максимальне значення відноситься до підвищеної підготовки.

Це обумовлено більшими витратами паливномастильних матеріалів для бойових літаків та заходами, необхідними для забезпечення цього процесу.

Для проведення порівняльної оцінки систем льотної підготовки, які були впроваджені до системи трьохступеневої системи льотної підготовки, експертами за визначеними процедурами була проведена оцінка попередніх систем льотної підготовки. Для порівняльної оцінки ефективності проведених заходів проведено окрему оцінку витрат для отримання “3 класу” в системі підготовки льотчиків до визначеного рівня на бойовому літаку у військових частинах у якості постійного складу за наступними альтернативами:

- витрати на основну льотну підготовку у вищому військовому навчальному закладів (BВН3) на літаку L-39 $\left(S_{2}^{*}\right)$;

- витрати на підготовку льотчика до визначеного рівня на бойовому літаку у військах $\left(S_{3}^{*}\right)$. 
Метою “Goal” (Витрати) є визначення у векторній формі витрат на відповідну систему льотної підготовки.

Отримання інтегральної оцінки економічного ефекту кожного етапу льотної підготовки шляхом оцінювання внеску кожної 3 визначених груп $\left\{X_{1}, \ldots X_{3}\right\}$ витрат в узагальнену оцінку витрат в цілому. Ієрархія представлена на рис. 3.

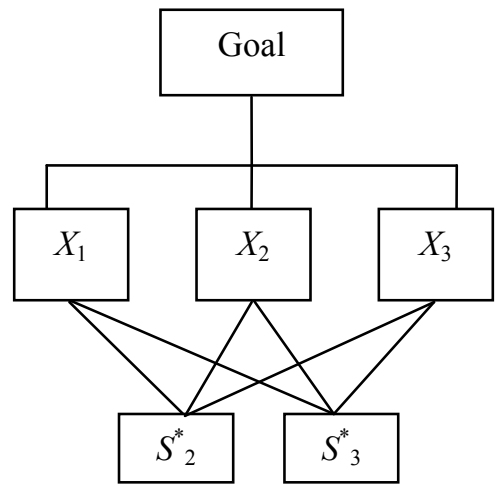

Рис. 3. Ієрархія визначення витрат на підготовку льотчиків

Результати порівняння об'єктів представлені в табл. 12-16. Для усіх МПП визначені відповідні оцінки локальних векторів пріоритету, максимальне власне значення, індекс погодженості та відношення погодженості, які описані у методичних підходах за MAI [4-9].

Таблиця 12

МПП критеріїв одного рівня ієрархії між собою

\begin{tabular}{|c|c|c|c|c|}
\hline Критерії & $X_{1}$ & $X_{2}$ & $X_{3}$ & Оцінка $W$ \\
\hline$X_{1}$ & 1 & $1 / 7$ & $1 / 9$ & 0,055 \\
\hline$X_{2}$ & 7 & 1 & $1 / 3$ & 0,29 \\
\hline$X_{3}$ & 9 & 1 & 1 & 0,655 \\
\hline
\end{tabular}

Локальний вектор пріоритетів складає $W=(0,055 ; 0,29 ; 0,655)$. Розраховані критерії погодженості МПП: $\lambda_{\max }=3,08, C I=0,04, \quad C R=6,92 \%$ дозволяють зробити висновок, що групове судження визначено $з$ достатнім ступенем достовірності.

Максимальне значення локального вектору пріоритету відповідає практичній підготовці $\left(X_{3}\right)$.

Таблиця 13

МПП альтернатив відносно критерію $X_{1}$

\begin{tabular}{|c|c|c|c|}
\hline $\begin{array}{c}\text { Критерій } \\
X_{1}\end{array}$ & $S^{*}{ }_{1}$ & $S^{*}{ }_{2}$ & Оцінка $W$ \\
\hline$S_{1}^{*}$ & 1 & 7 & 0,785 \\
\hline$S^{* 2}$ & $1 / 7$ & 1 & 0,215 \\
\hline
\end{tabular}

Порівняння альтернатив відносно витрат на теоретичну підготовку $\left(X_{1}\right)$, що склали $W=(0,785$; 0,215). Критерії погодженості складають $\lambda_{\text {max }}=2,615, C I=0,615, C R=0 \%$.

Максимальне значення витрат відносно теоретичної підготовки складає підготовка на літаку L-39.
Таблиця 14

МПП альтернатив відносно критерію $X_{2}$

\begin{tabular}{|c|c|c|c|}
\hline $\begin{array}{c}\text { Критерій } \\
X_{2}\end{array}$ & $S^{*}{ }_{1}$ & $S^{*}{ }_{2}$ & Оцінка $W$ \\
\hline$S_{1}{ }_{1}$ & 1 & 3 & 0,675 \\
\hline$S_{2}{ }_{2}$ & $1 / 3$ & 1 & 0,325 \\
\hline
\end{tabular}

Порівняння альтернатив відносно витрат на тренажерну підготовку $\left(X_{2}\right)$, що склали $W=(0,675$; 0,325). Критерії погодженості складають $\lambda_{\max }=2,199, C I=0,199, C R=0 \%$. Максимальне значення витрат відносно тренажерної підготовки складає підготовка на літаку L-39.

Таблиця 15

МПП альтернатив відносно критерію $\mathrm{X}_{3}$

\begin{tabular}{|c|c|c|c|}
\hline $\begin{array}{c}\text { Критерій } \\
X_{3}\end{array}$ & $S_{1}^{*}$ & $S_{2}^{*}$ & Оцінка $W$ \\
\hline$S_{1}{ }_{1}$ & 1 & $1 / 7$ & 0,215 \\
\hline$S_{2}^{*}$ & 7 & 1 & 0,785 \\
\hline
\end{tabular}

Порівняння альтернатив відносно витрат на практичну підготовку $\left(X_{3}\right)$, що склали $W=(0,215$; 0,785). Критерії погодженості складають $\lambda_{\text {max }}=2,615, C I=0,615, C R=0 \%$.

Максимальне значення витрат відносно тренажерної підготовки складає підготовка на бойових літаках безпосередньо у військових частинах. Це обумовлено більшою витратністю на збереження, обслуговування та амортизацію авіаційної техніки, грошове забезпечення особового складу, тощо.

Таблиця 16

Визначення загальних пріоритетів

\begin{tabular}{|c|c|c|c|c|}
\hline \multirow{2}{*}{$\begin{array}{c}\text { Альтерна- } \\
\text { тиви }\end{array}$} & \multicolumn{4}{|c|}{ Критерії } \\
\cline { 2 - 4 } & $X_{1}$ & $X_{2}$ & $X_{3}$ & $\begin{array}{c}\text { Вектор } \\
\text { пріоритетів }\end{array}$ \\
\hline$S_{1}^{*}$ & 0,055 & 0,29 & 0,655 & 0,38 \\
\hline$S_{2}^{*}$ & 0,785 & 0,675 & 0,215 & 0,215 \\
\hline
\end{tabular}

Як видно з проведених досліджень, у векторній відносній величині витрат, максимальне значення відноситься до альтернативи $S_{2}^{*}$ щодо підготовки на бойовому літаку у військах.

3 огляду варіантів підготовки льотчиків для потреб тактичної авіації Повітряних Сил Збройних Сил України розглянуто варіант підготовки первинної та основної ступені льотної підготовки у ВВНЗ та опанування бойового літака у відповідних бойових частинах з отриманням “3 класу”. Слід зазначити, що подібна система може бути розглянута як альтернатива системі льотної підготовки на прогнозований термін при прискореній підготовці фахівців льотного профілю.

Результати розрахунків векторного значення витрат представлено в табл. 17-22. Оцінкою витрат на підготовку буде визначення витрат при підготовці льотчика до рівня “3 класу” поетапно у вищому навчальному закладі та подальше у військах: 
- первинна льотна підготовка $\left(S_{\mathrm{i} 1}\right)$;

- основна льотна підготовка $\left(S_{\mathrm{i} 2}\right)$;

- підготовка на бойовому літаку у військових частинах $\left(S_{\mathrm{i} 3}\right)$.

Метою "Goal” (Витрати) є визначення пріоритету у векторній формі витрат на відповідну систему льотної підготовки. Ієрархія представлена на рис. 4.

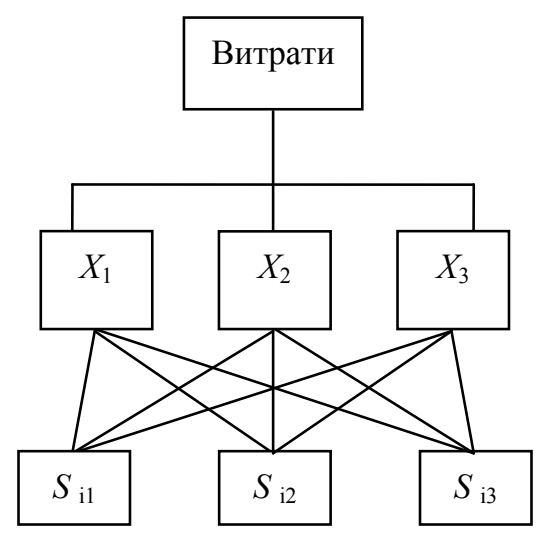

Рис. 4. Ієрархія визначення витрат на льотну підготовку

Результати порівняння об'єктів дослідження представлені в табл. 17-22.

Таблиця 17

МПП критеріїв одного рівня ієрархії між собою

\begin{tabular}{|c|c|c|c|c|}
\hline Критерії & $X_{1}$ & $X_{2}$ & $X_{3}$ & $\begin{array}{c}\text { Оцінка } \\
W\end{array}$ \\
\hline$X_{1}$ & 1 & $1 / 7$ & $1 / 9$ & 0,055 \\
\hline$X_{2}$ & 7 & 1 & $1 / 3$ & 0,29 \\
\hline$X_{3}$ & 9 & 3 & 1 & 0,655 \\
\hline
\end{tabular}

Локальний вектор пріоритетів складає $W=(0,055 ; 0,29 ; 0,655)$. Розраховані критерії погодженості МПП: $\lambda_{\max }=3,08, C I=0,04, C R=6,92 \%$ дозволяють зробити висновок, що групове судження визначено з достатнім ступенем достовірності.

Максимальне значення локального вектору пріоритету можна віднести до практичної підготовки $\left(X_{3}\right)$.

Таблиця 18

МПП альтернатив відносно критерію $X_{1}$

\begin{tabular}{|c|c|c|c|c|}
\hline $\begin{array}{c}\text { Критерій } \\
X_{1}\end{array}$ & $S_{\mathrm{i} 1}$ & $S_{\mathrm{i} 2}$ & $S_{\mathrm{i} 3}$ & $\begin{array}{c}\text { Оці- } \\
\text { нка } \\
W\end{array}$ \\
\hline$S_{\mathrm{i} 1}$ & 1 & $1 / 6$ & $1 / 5$ & 0,073 \\
\hline$S_{\mathrm{i} 2}$ & 6 & 1 & 5 & 0,702 \\
\hline$S_{\mathrm{i} 3}$ & 5 & $1 / 5$ & 1 & 0,225 \\
\hline
\end{tabular}

Порівняння альтернатив відносно витрат на теоретичну підготовку $\left(X_{1}\right)$ дозволило розрахувати значення локальних векторів пріоритетів, що склали $W=(0,073 ; 0,702 ; 0,226)$. Критерії погодженості складають $\lambda_{\max }=3,231, C I=0,115, C R=19,88 \%$, а тому, групове судження визначено 3 достатнім ступенем достовірності.
Максимальне значення витрат відносно теоретичної підготовки отримала альтернатива $S_{\mathrm{i} 2}-$ основна льотна підготовка.

Таблиця 19

МПП альтернатив відносно критерію $X_{2}$

\begin{tabular}{|c|c|c|c|c|}
\hline $\begin{array}{c}\text { Критерій } \\
X_{2}\end{array}$ & $S_{\mathrm{i} 1}$ & $S_{\mathrm{i} 2}$ & $S_{\mathrm{i} 3}$ & $\begin{array}{c}\text { Оцінка } \\
W\end{array}$ \\
\hline$S_{\mathrm{i} 1}$ & 1 & $1 / 3$ & $1 / 5$ & 0,109 \\
\hline$S_{\mathrm{i} 2}$ & 3 & 1 & $1 / 2$ & 0,309 \\
\hline$S_{\mathrm{i} 3}$ & 5 & 2 & 1 & 0,582 \\
\hline
\end{tabular}

При порівнянні альтернатив, щодо витрат відносно тренажерної підготовки $\left(X_{2}\right)$, значення локального вектору пріоритетів склали $W=(0,109 ; 0,309$; 0,582) критерії погодженості: $\lambda_{\max }=3,004$, $C I=0,002, C R=0,32 \%$, що в межах визначеного за обраним методом.

Максимальне значення витрат відносно теоретичної підготовки отримала альтернатива $S_{\text {iз }}-$ підготовка на бойовому літаку у військових частинах.

Таблиця 20

МПП альтернатив відносно критерію $X_{3}$

\begin{tabular}{|c|c|c|c|c|}
\hline $\begin{array}{c}\text { Критерій } \\
X_{3}\end{array}$ & $S_{\mathrm{i} 1}$ & $S_{\mathrm{i} 2}$ & $S_{\mathrm{i} 3}$ & $\begin{array}{c}\text { Оцінка } \\
W\end{array}$ \\
\hline$S_{\mathrm{i} 1}$ & 1 & $1 / 7$ & $1 / 9$ & 0,055 \\
\hline$S_{\mathrm{i} 2}$ & 7 & 1 & $1 / 3$ & 0,29 \\
\hline$S_{\mathrm{i} 3}$ & 9 & 3 & 1 & 0,655 \\
\hline
\end{tabular}

Групове експертне судження експертів визначило найбільш витратним практичну підготовку на бойових літаках відносно критерію $\left(X_{3}\right)$. Вектор локальних пріоритетів має наступні значення $W=(0,055 ; 0,29 ; 0,655)$. Критерії погодженості складають $\lambda_{\max }=3,08, C I=0,04, C R=6,92 \%$, що свідчить про потенційно велику погодженість групового судження експертів за даним питанням.

Таблиця 21

Визначення загальних пріоритетів

\begin{tabular}{|c|c|c|c|c|}
\hline \multirow{2}{*}{$\begin{array}{c}\text { Альтерна- } \\
\text { тиви }\end{array}$} & \multicolumn{4}{|c|}{ Критерії } \\
\cline { 2 - 4 } & $X_{1}$ & $X_{2}$ & $X_{3}$ & $\begin{array}{c}\text { Вектор } \\
\text { пріоритетів }\end{array}$ \\
\hline$S_{\mathrm{i} 1}$ & 0,055 & 0,29 & 0,655 & прі \\
\hline$S_{\mathrm{i} 2}$ & 0,073 & 0,109 & 0,055 & 0,07 \\
\hline$S_{\mathrm{i} 3}$ & 0,226 & 0,309 & 0,29 & 0,32 \\
\hline
\end{tabular}

Як видно з проведених досліджень, у векторній відносній величині витрат, максимальне значення відноситься до підготовки на бойових літаках у військових частинах. 3 проведеного аналізу відносних значень витрат та ефекту можна зробити висновок про те, що максимальні значення ефекту досягаються при застосуванні підвищеної льотної підготовки на відповідних бойових літаках та мають більш витратні показники.

Для подальшого аналізу і відповідного порівняння за виразом (1) розраховані комплексні коефі- 
цієнти ефективності етапів системи льотної підготовки. Вихідні дані та результати зведені до табл. 22.

Таблиця 22

Результати проведених досліджень

\begin{tabular}{|c|c|c|c|}
\hline $\begin{array}{c}\text { № } \\
\text { системи }\end{array}$ & Ефект & Витрати $_{\mathrm{j}}$ & $\boldsymbol{\Omega}_{\text {eфj }}$ \\
\hline \multirow{3}{*}{1} & $\mathrm{P}_{1}=0,07$ & $\mathrm{~S}_{\mathrm{i} 1}=0,07$ & 1 \\
\cline { 2 - 4 } & $\mathrm{P}_{2}=0,41$ & $\mathrm{~S}_{\mathrm{i} 2}=0,32$ & 1,28 \\
\cline { 2 - 4 } & $\mathrm{P}_{3}=052$ & $\mathrm{~S}_{\mathrm{i} 3}=0,61$ & 0,85 \\
\hline \multirow{2}{*}{2} & $\mathrm{P}_{2}=0,41$ & $\mathrm{~S}_{2}{ }_{2}=0,38$ & 1,16 \\
\cline { 2 - 4 } & $\mathrm{P}_{3}=0,52$ & $\mathrm{~S}_{3}^{*}=0,62$ & 0,84 \\
\hline \multirow{3}{*}{3} & $\mathrm{P}_{1}=0,07$ & $\mathrm{~S}_{1}=0,07$ & 1 \\
\cline { 2 - 4 } & $\mathrm{P}_{2}=0,41$ & $\mathrm{~S}_{2}=0,44$ & 0,93 \\
\cline { 2 - 4 } & $\mathrm{P}_{3}=0,52$ & $\mathrm{~S}_{3}=0,49$ & 1,06 \\
\hline
\end{tabular}

Оскільки найбільш вагомий ефект для отримання льотним складом класності “3 клас" в систему льотної підготовки вносить підготовка на бойових літаках. Проведено порівняльну оцінку значень комплексного критерію оцінки ефективності системи льотної підготовки за роками впроваджених систем. Побудована ретроспективна діаграма зміни комплексного критерію оцінки ефективності системи льотної підготовки за роками застосування систем льотної підготовки, що застосовувалися рис. 5.

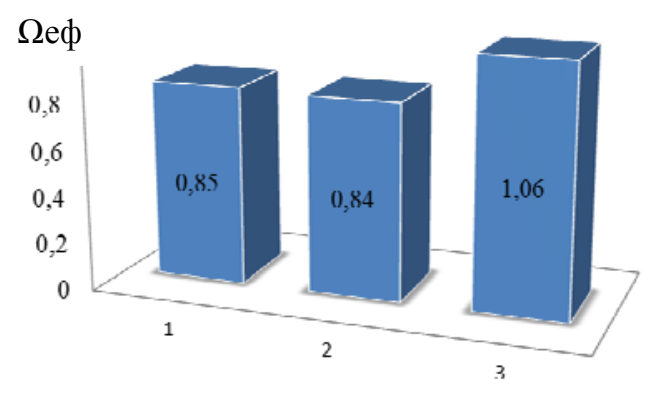

Рис. 5. Ретроспективна діаграма комплексного критерію оцінки ефективності підвищеного рівня системи льотної підготовки
На осі абсцис розміщені номери систем льотної підготовки, які були запроваджені у ВВН3 за роками.

Як видно з побудованої діаграми перевага відноситься до трьохступеневої системи льотної підготовки курсантів.

\section{Висновки}

Таким чином, шляхом порівняння критерію оцінки ефективності системи льотної підготовки курсантів льотчиків тактичної авіації ПС ЗС України при визначеній меті досягнення класної кваліфікації льотчика "3 класу” перевагу отримує система трьохступеневої системи льотної підготовки, яка на 20,8\% має більше значення по відношенню до системи підготовки, в якій льотний склад тільки починав виконання програми польотів на бойових літаках у військових частинах без підготовки на ЛМЛ початкового навчання та на 20\% більше за підготовку із підготовкою на ЛМЛ.

Серед факторів, що обумовлюють отриману перевагу можна додати: часові показники на підготовку, забезпечення та утримання авіаційного персоналу та авіаційної техніки, які за розрахованими векторними показниками менші за попередні роки.

Підготовлений особовий склад здатний виконувати завдання за призначенням без додаткової підготовки (перепідготовки), що скорочує витрати на бойову підготовку в цілому.

Отримані результати дозволяють у кількісній формі провести оцінку запровадженої трьохступеневої системи підготовки курсантів льотчиків для потреб тактичної авіації ПС ЗС України.

Розроблені кваліметрична модель та методичний підхід дозволяють проводити порівняльний аналіз систем підготовки на прогнозований період та надавати рекомендації щодо покращення системи льотної підготовки в системи бойової підготовки тактичної авіації ПС Збройних Сил України.

\section{Список літератури}

1. Уткин В.Ф. Эффективность технических систем / В.Ф. Уткин, Ю.В. Крючков. - М.: Машиностроение, 1988. - 328 с.

2. Горбенко В.М. Удосконалена математична модель повітряної дуелі з урахуванням фактичного рівня підготовки льотного складу / В.М. Горбенко, В.В. Герасименко, О.М. Компанієць // Збірник наукових праць Харківського університету Повітряних Сил. - 2010. - № 4(26). - С. 107-112.

3. Сідаш В.В. Інноваційний розвиток вищої військової освіти України: досвід, тенденції, перспективи, особливості підготовки військових льотчиків: монографія / В.В. Сідаш, А.М. Алімпієв, Г.В. Пєвцов. - Х.: Цифрова друкарня, 2012. - 456 с.

4. Методика векторного оцінювання ефективності виконання етапів проекту / О.М. Компанієць, Д.В. Литвинчук, Г.В. Дубовик, І.Ю. Гридасов // Інтернаука. - 2019. - № $14 . \quad$ - Режим доступу: http://www.internauka.com/issuse/2019/14/5251.

5. Саати Т. Принятие решений. Метод анализа иерархий / Т. Саати. - М.: Радио и связь, 1993. - 31 с.

6. Саати Т. Принятие решений при зависимостях и обратных связях: Аналитические сети / Т. Саати. - М.: ЛКИ, 2008. $-360 \mathrm{c}$.

7. Короблев Н.М. Согласование и коррекция экспертных оценок в системах поддержки принятия решений в условиях нечеткой исходной информации / Н.М. Короблев, С.Г. Удовенко // Радіоелектроніка. Інформатика. Управління. 2005. - № 2. - C. 116-120.

8. Визначення вагового внеску основних груп властивостей ударного авіаційного комплексу в узагальнений показ- 
ник бойової ефективності шляхом експертного оцінювання / О.Б. Леонтьєв, Д.А. Гриб, Є.О. Українець, О.М. Компанієць // Збірник наукових праць Харківського університету Повітряних Сил. - 2009. - № 3(21). - С. 5-10.

9. Компанієць О.М. Методика оцінювання коефіцієнту бойового потенціалу літаків тактичної авіації / О.М. Компанієць // Системи управління, навігації та зв’язок. - 2009. - № 3(11). - С. 173-177.

10. Обгрунтування шляхів удосконалення методики оцінювання узагальненого показника якості авіаційного комплексу зі спеціальним обладнанням / О.Б. Леонтьєв, В.І. Нікітченко, А.Г. Дмитрієв, О.М. Компанієць // Збірник наукових праць Державного науково-дослідного інституту авіації. - 2010. - № 6(13). - С. 79-86.

11. Компанієць О.М. Методика оцінки бойового потенціалу ударних авіаційних комплексів при виконанні ними вогневих задач / О.М. Компанієць, О.Б. Леонтьєв, В.В. Шмаков // Збірник наукових праць Харківського університету Повітряних Сил. - 2008. - № 2(17). - С. 20-23.

12. Системная методология планирования развития, предпроектных исследований и внешнего проектирования вооружения и военной техники / Б.А. Демидов, М.И. Луханин, А.Ф. Величко, М.В. Науменко. - К.: Стилос, 2011. - 464 с.

\section{References}

1. Utkin, V.F. and Kryuchkov, Yu.V. (1988), "Effektivnost' tekhnicheskikh sistem" [Efficiency of technical systems], Engineering, Moscow, $328 \mathrm{p}$.

2. Gorbenko, V.M., Gerasimenko, V.V. and Kompaniets, O.M., (2010), “Udoskonalena matematychna model povitryanoyi dueli z urakhuvannyam faktychnoho rivnya pidhotovky lyotnoho skladu" [Improved mathematical model of the air duel taking into account the actual level of training of the flight composition], Scientific Works of Kharkiv National Air Force University, No. 4 (26), pp. 107-112.

3. Sidash, V.V., Olimpiyev, A.M. and Singers, G.V. (2012), "Innovative working higher education institution of Ukraine: experience, tendencies, prospects, peculiarities of activity of the last pilots" [Innovatsiinyi rozvytok vyshchoi viiskovoi osvity Ukrainy: dosvid, tendentsii, perspektyvy, osoblyvosti pidhotovky viiskovykh lotchykiv], Digital Printing House, Kharkiv, 456 p.

4. Kompaniiets, O.M., Litvinchuk, D.V., Dubovik, G.V. and Gridasov, I.Yu. (2019), "Metodyka vektornoho otsinyuvannya efektyvnosti vykonannya etapiv proektu" [The methodology of vector evaluation of the efficiency of the project stages] Internship, No. 14, pp. 62-68, available at: www.inter-nauka.com/issuse/2019/14/5251.

5. Saati, T. (1993), "Prinyatiye resheniy. Metod analiza iyerarkhiy" [Decision Making. Hierarchy Analysis Method], Radio and Communications, Moscow, $31 \mathrm{p}$.

6. Saati, T. (2008), "Prinyatiye resheniy pri zavisimostyakh i obratnykh svyazyakh: Analiticheskiye seti" [Decision making with dependencies and feedbacks: Analytical networks], LCI, Moscow, 360 p.

7. Koroblev, N.M. and Udovenko, S.G. (2005), "Soglasovaniye i korrektsiya eksper-tnykh otsenok v sistemakh podderzhki prinyatiya re-sheniy v usloviyakh nechetkoy iskhodnoy informatsii" [Coordination and correction of expert assessments in decision support systems in the conditions of fuzzy initial information], Radio-Electronic. Informatics. Management, No. 2, pp. 116-120.

8. Leont'ev, O.B., Gryb, D.A., Ukrainets, E.O. and Kompaniiets, O.M. (2009), "Vyznachennya vahovoho vnesku osnovnykh hrup vlastyvostey udarnoho aviatsiynoho kompleksu v uzahalnenyy pokaznyk boyovoyi efektyvnosti shlyahom ekspertnoho otsinyuvannyu" [Determination of the weight contribution of the main groups of properties of the strike aviation complex in the generalized indicator of combat effectiveness through expert evaluation], Collection of Scientific Works of Kharkiv National Air Force University, No. 3(21), pp. 5-10.

9. Company, O.M. (2009), "The companion OM Methods of estimation of the combat potential of tactical aviation aircraft" [Metodyka otsiniuvannia koefitsiientu boiovoho potentsialu litakiv taktychnoi aviatsii], Management, Navigation and Communication Systems, No. 3(11), pp. 173-177.

10. Leont'ev, O.B., Nikitchenko, V.I., Dmitriev, A.G. and Companyez, O.M. (2010), "Substantiation of ways of improvement of the method of estimation of the generalized indicator of quality of the aviation complex with special equipment" [Obgruntuvannia shliakhiv udoskonalennia metodyky otsiniuvannia uzahalnenoho pokaznyka yakosti aviatsiinoho kompleksu zi spetsialnym obladnanniam], Collection of Scientific Works of the State Aviation Research Institute, No. 6(13), pp. 79-86.

11. Kompaniiets, O.M., Leontiev, O.B. and Shmakov, V.V. (2008), "Methods of evaluation of combat potential of striking aviation complexes when performing fire tasks" [Metodyka otsinky boiovoho potentsialu udarnykh aviatsiinykh kompleksiv pry vykonanni nymy vohnevykh zadach], Collection of Scientific Works of Kharkiv National Air Force University, No. 2(17), pp. 20-23.

12. Demydov, B.A., Lukhanyn, M.Y., Velychko, A.F. and Naumenko, M.V. (2011), "Systemnaia metodolohyia planyrovanyia razvytyia, predproektnykh yssledovanyi y vneshneho proektyrovanyia vooruzhenyia y voennoi tekhnyky" [System methodology for development planning, feasibility studies and external design of weapons and military equipment], Stylos, Kyiv, 464 p.

Надійшла до редколегії 21.01.2020

Схвалена до друку 11.02.2020

\author{
Відомості про авторів: \\ Вовк Олексій Вікторович \\ кандидат військових наук \\ начальник факультету \\ Харківського національного університету \\ Повітряних Сил ім. І. Кожедуба, \\ Харків, Україна \\ https://orcid.org/0000-0003-3356-9343
}

Information about the authors:

Oleksii Vovk

Candidate of Military Sciences

Chief of the Faculty

of Ivan Kozhedub Kharkiv

National Air Force University,

Kharkiv, Ukraine

https://orcid.org/0000-0003-3356-9343 
Іщук Віктор Олександрович

начальник кафедри

Харківського національного

університету Повітряних Сил ім. І. Кожедуба,

Харків, Україна

https://orcid.org/0000-0003-0266-3679

\section{Компанісць Олег Миколайович}

кандидат технічних наук

начальник науково-дослідної лабораторії

Харківського національного університету

Повітряних Сил ім. І. Кожедуба,

Харків, Україна

https://orcid.org/0000-0001-7472-0869

Литвинчук Дмитро Валерійович

науковий співробітник

науково-дослідної лабораторії

Харківського національного університету

Повітряних Сил ім. І. Кожедуба,

Харків, Україна

https://orcid.org/0000-0002-0655-4798

Туленко Михайло Володимирович викладач

Харківського національного університету

Повітряних Сил ім. І. Кожедуба,

Харків, Україна

https://orcid.org/0000-0003-4484-2069
Viktor Ischuk

Chief of the Department

of Ivan Kozhedub Kharkiv

National Air Force University,

Kharkiv, Ukraine

https://orcid.org/0000-0003-0266-3679

Oleg Kompaniiets

Candidate of Technical Sciences

Chief of the Research Laboratory

of Ivan Kozhedub Kharkiv

National Air Force University,

Kharkiv, Ukraine

https://orcid.org/0000-0001-7472-0869

\section{Dmitriy Litvinchuk}

Research Associate

of the Research Laboratory

of Ivan Kozhedub Kharkiv

National Air Force University,

Kharkiv, Ukraine

https://orcid.org/0000-0002-0655-4798

\author{
Michael Tulenko \\ Instructor \\ of Ivan Kozhedub Kharkiv \\ National Air Force University, \\ Kharkiv, Ukraine \\ https://orcid.org/0000-0003-4484-2069
}

\section{РЕЗУЛЬТАТЫ СРАВНИТЕЛЬНОЙ ОЦЕНКИ СИСТЕМЫ ЛЕТНОЙ ПОДГОТОВКИ КУРСАНТОВ ЛЕТЧИКОВ ТАКТИЧЕСКОЙ АВИАЦИИ ВОЗДУШНЫХ СИЛ ВООРУЖЕННЫХ СИЛ УКРАИНЫ КОМПЛЕКСНЫМ КРИТЕРИЕМ ОЦЕНКИ ЭФФЕКТИВНОСТИ}

А.В. Вовк, В.А. Ищук, О.Н. Компаниец, Д.В. Литвинчук, М.В. Туленко

Разработана квалиметрическая модель оценки системы лётной подготовки курсантов летчиков тактической авищии Воздушных Сил Вооруженных Сил Украины, которая в векторной форме позволяет осуществить оценку эффективности внедрённых соответствующих систем подготовки. Проведен расчет значений комплексного критерия оценки эффективности системы лётной подготовки, внедрённой в Харьковском национальном университете Воздушных Сил. Полученные результаты позволяют учитывать особенности лётной подготовки и их влияние на систему боевой подготовки Воздушных Сил Вооруженных Сил Украиныл.

Ключевые слова: трехступенчатая система подготовки, уровень подготовки летного состава, эффективность.

\section{RESULTS OF A COMPARATIVE EVALUATION OF THE FLIGHT TRAINING SYSTEM OF TACTICAL AIRCRAFT PILOTS OF THE ARMED FORCES OF UKRAINE IN THE COMPLEX CRITERION FOR ESTIMATING EFFICIENCY}

O. Vovk, V. Ischuk, O. Kompaniiets, D. Litvinchuk, M. Tulenko

Analyzed are approaches to assessing the effectiveness of various systems that allow you to build mathematical models to calculate indicators of their effectiveness. The effectiveness of the three-stage system of flight training of cadets of tactical aviation pilots, introduced at Kharkov National University of Air Force, was assessed by comparison with known alternatives to systems that were used earlier or those that could be introduced in the future. A comprehensive criterion has been applied to assess the effectiveness of flight training of cadets for pilots for tactical aviation of the Air Force of the Armed Forces of Ukraine. A qualimetric model has been developed for assessing the flight training system for cadets of tactical aviation pilots of the Air Forces of the Armed Forces of Ukraine, which in vector form allows evaluating the effectiveness of the relevant training systems implemented. Based on the analysis of the flight training of cadets, heuristic methods determine the groups of skills. Cadets should master them during their training and be selected as a set of properties to determine the effect of flight training. The hierarchies of achieving the effect of the implementation of the corresponding flight training systems are built and expenditure indicators are determined. Calculations were performed in vector form according to expert analytical procedures, which are determined by the method of hierarchy analysis and corresponding ranking of certain indicators at lower levels of the hierarchy was carried out. The group judgments of experts are determined. The external criteria for consistency of the qualimetric model are calculated. The studies conducted a comparative assessment of the effectiveness of the measures taken, a separate assessment of the vector value of expenditures for obtaining classy qualifications of flight personnel in the system of training pilots for a certain level on a combat aircraft in military units was carried out. A retrospective diagram of the change in the comprehensive criterion for assessing the effectiveness of the flight training system by years of application of flight training systems is constructed. The results obtained allow taking into account the peculiarities of flight training and their impact on the combat training system of the Air Forces of the Armed Forces of Ukraine.

Keywords: three-stage training system, the level of training of flight personnel, efficiency. 